\title{
NILAI PENDIDIKAN KARAKTER DALAM NOVEL KIDUNG DARI NEGERI APUNG KARYA ARSYAD SALAM
}

\author{
Oleh \\ Muhammad Dinil Ahiri \\ Marwati ${ }^{2}$ \\ NIDN: ooloo57708; marwatipbsiuho@gmail.com
}

\begin{abstract}
Abstrak
Pendidikan karakter merupakan sebuah istilah yang semakin hari semakin mendapatkan pengakuan dari masyarakat Indonesia. Pendidikan karakter merupakan bagian penting yang tidak bisa dipisahkan dalam isi pendidikan kita. Novel Kidung dari Negeri Apung adalah sebuah novel karya Arsyad Salam yang diterbitkan oleh Gramedia pada April 2015. Novel ini menceritakan perjuangan seorang wanita yang bernama Liana yang ingin memajukan desanya melalui pendidikan meskipun mendapat tentangan dari orang-orang desa. Masalah utama dalam penelitian ini adalah Nilai-nilai pendidikan karakter yang ditemukan pada novel tersebut akan direlevansikan pada pembelajaran bahasa Indonesia di SMA. nilai-nilai pendidikan karakter apa sajakah yang terdapat dalam novel Kidung dari Negeri Apung karya Arsyad Salam? Penelitian ini bertujuan untuk mengetahui dan mendeskripsikan nilai-nilai pendidikan karakter yang terdapat dalam novel Kidung dari Negeri Apung karya Arsyad Salam. Penelitian ini menggunakan metode deskriptif kualitatif dimana data yang dianalisis dan hasil analisisnya berbentuk deskripsi. Teknik yang akan digunakan untuk mengumpulkan data dalam penelitian ini adalah baca-catat. Metode yang digunakan dalam penelitian ini adalah metode deskriptif. Berdasarkan hasil penelitian dan pembahasan dapat disimpulkan bahwa terdapat nilai-nilai pendidikan karakter dalam novel Kidung dari Negeri Apung karya Arsyad Salam diantaranya kerja keras, peduli sosial, peduli lingkungan, rasa ingin tahu, tanggung jawab, cinta tanah air, cinta damai, komunikatif, kreatif, dan mandiri. Nilai pendidikan karakter tersebut memberikan efek positif bagi pembaca novel Kidung dari Negeri Apung karya Arsyad Salam khususnya guru dan siswa.
\end{abstract}

Kata Kunci: Nilai Pendidikan, Karakter, pada Pembelajaran Novel.

\begin{abstract}
Abstrack
\footnotetext{
${ }^{1}$ Alumni Pendidikan Bahasa Indonesia FKIP UHO

${ }^{2}$ Dosen Pendidikan Bahasa Indonesia FKIP UHO
}

Character education is a term that is increasingly gaining recognition from the people of Indonesia. Character education is an important part that cannot be separated from the content of our education. Novel Kidung from Negeri Apung is a novel by Arsyad Salam published by Gramedia in April 2015. This novel tells the story of the struggle of a woman named Liana who wanted to advance her village through education despite opposition from villagers. The 
main problem in this study is that the character education values found in the novel will be reflected in the learning of Indonesian in high school. what character education values are contained in the Kidung novel from the Floating Country by Arsyad Salam? This study aims to determine and describe the values of character education found in the novel Kidung from the Land of Floating by Arsyad Salam. This study uses a qualitative descriptive method where the data is analyzed and the results of the analysis are in the form of descriptions. The technique that will be used to collect data in this study is to note. The method used in this research is descriptive method. Based on the results of the research and discussion it can be concluded that there are character education values in the Kidung novel from the Apung Negeri by Arsyad Salam including hard work, social care, environmental care, curiosity, responsibility, love for the country, peace, communicative, creative, and independent. The value of character education has a positive effect on the readers of the novel Kidung from the Floating Land by Arsyad Salam, especially teachers and students.

Keywords: Value of Education, Character, on Novel Learning.

\section{PENDAHULUAN}

Karya sastra sebagai bentuk dan hasil sebuah pekerjaan kreatif, pada hakikatnya adalah suatu media yang mendayagunakan bahasa untuk mengungkapkan tentang kehidupan manusia. Oleh sebab itu, sebuah karya sastra pada umumnya berisi permasalahan yang melingkupi kehidupan manusia. Macam-macam hasil karya sastra sangatlah banyak. Dari sekian banyak bentuk sastra seperti esai, puisi, novel, cerita pendek, drama, bentuk novel, cerita pendeklah yang paling banyak dibaca oleh para pembaca. Karyakarya modern klasik dalam kesusasteraan, kebanyakan juga berisi karya-karya novel.

Novel adalah salah satu bentuk dari sebuah karya sastra. Novel merupakan cerita fiksi dalam bentuk tulisan atau kata-kata dan mempunyai unsur instrinsik dan ekstrinsik. Sebuah novel biasanya menceritakan kehidupan manusia dalam berinteraksi dengan lingkungan dan sesamanya. Dalam sebuah novel, si pengarang berusaha semaksimal mungkin untuk mengarahkan pembaca kepada gambarangambaran realitas kehidupan melalui cerita yang terkandung dalam novel tersebut. Menurut khasanah kesusastraan Indonesia modern, novel berbeda dengan roman. Sebuah roman menyajikan alur cerita yang lebih kompleks dan jumlah pemeran (tokoh cerita) juga lebih banyak. Hal ini sangat berbeda dengan novel yang lebih sederhana dalam penyajian alur cerita dan tokoh cerita yang ditampilkan dalam cerita tidak terlalu banyak. Hasil kreativitas pengarang adalah melahirkan suatu karya seni yang berupa karya sastra. Di dalam karya sastra terdapat unsur-unsur yang mendukung terbentuknya suatu karya sastra. Pengarang dalam menciptakan suatu karya sastra sangat memperhatikan unsur-unsur yang mendukung karya tersebut baik intrinsik maupun ekstrinsik. 
Pendidikan karakter merupakan sebuah istilah yang semakin hari semakin mendapatkan pengakuan dari masyarakat Indonesia. Terlebih dengan dirasakannya berbagai ketimpangan hasil pendidikan dilihat dari perilaku lulusan pendidikan formal. Pendidikan karakter bukanlah hal baru dalam dunia pendidikan kita ini. Pendidikan karakter sudah dikenal sejak dulu, Ki Hajar Dewantara telah memperkenalkan pendidikan karakter pada dunia pendidikan. Pendidikan karakter merupakan bagian penting yang tidak bisa dipisahkan dalam isi pendidikan kita. Sekarang ini, Indonesia sedang mengalami krisis pendidikan karakter. Dapat kita lihat sekarang ini banyak terjadi tindakan korupsi, itu semua karena kurangnya pendidikan karakter dalam diri seseorang. Dapat kita lihat pula pada keadaan siswa-siswa di Indonesia. Sering kita jumpai siswa-siswi tidak memiliki karakter yang baik dalam dirinya. Seperti, kurang sopan pada orang yang lebih tua, sering melakukan tawuran, dan lain sebagainya. Hal tersebut membuktikan bahwa siswa-siswi di Indonesia mengalami krisis pendidikan karakter dan sebagai seorang calon pendidik yang sadar akan pentingnya pendidikan karakter, dalam penelitian ini penulis tertarik sekali untuk mengkaji nilai-nilai pendidikan karakter yang terdapat pada novel Kidung dari Negeri Apung karya Arsyad Salam. Nilai-nilai pendidikan tersebut nantinya akan diimplementasikan pada peserta didik melalui pembelajaran bahasa Indonesia.

Novel Kidung dari Negeri Apung adalah sebuah novel karya Arsyad Salam yang diterbitkan oleh Gramedia pada April 2015. Novel ini menceritakan perjuangan seorang wanita yang bernama Liana yang ingin memajukan desanya melalui pendidikan meskipun mendapat tentangan dari orang-orang desa. Liana memiliki watak yang gigih, berani berbuat benar, dan juga memiliki watak yang peduli terhadap lingkungan sekitarnya terutama di bidang pendidikan. Dalam kegigihannya untuk menyadarkan warganya akan pentingnya pendidikan, ia melakukan segala cara untuk menarik minat warga dan anak-anak terhadap dunia pendidikan. Mulai dari memasuki rumah-rumah warga untuk meminta anaknya didaftarkan di sekolah, hingga membuat sebuah program tamasya terumbu karang di Pulau Bokori.

Nilai-nilai pendidikan karakter yang ditemukan pada novel tersebut akan direlevansikan pada pembelajaran bahasa Indonesia di SMA. Salah satunya adalah nilai karakter mandiri. Guru dapat mengimplementasikan nilai karakter mandiri tersebut dalam pembelajaran, yaitu mandiri dalam mengerjakan tugas individu, mandiri dalam mengerjakan ulangan, dan lain sebagainya. Pada penelitian ini penulis akan mengkaji dan menemukan dan menjelaskan nilai-nilai pendidikan karakter yang tercermin dalam novel karya Arsyad Salam berjudul Kidung dari Negeri Apung serta menemukan bagaimana relevansinya terhadap materi pembelajaran Bahasa Indonesia di SMA. Berdasarkan latar belakang yang telah dipaparkan, maka masalah dalam penelitian ini adalah nilai-nilai pendidikan karakter apa sajakah yang terdapat dalam novel Kidung dari Negeri Apung karya Arsyad Salam?. Penelitian ini bertujuan untuk mengetahui dan mendeskripsikan nilai-nilai pendidikan karakter yang terdapat dalam novel Kidung dari Negeri Apung karya Arsyad Salam. 


\section{Jenis dan Metode Penelitian}

Jenis penelitian yang akan digunakan dalam penelitian ini adalah penelitian kepustakaan, yakni penelitian yang didukung oleh referensi baik berupa teks dalam novel maupun buku-buku dan sumber penunjang lainnya yang mampu memecahkan masalah dalam penelitian ini.

Penelitian ini menggunakan metode deskriptif kualitatif diman data yang dianalisis dan hasil analisisnya berbentuk deskripsi. Metode kualitatif memberikan perhatian terhadap data alamiah, data dalam hubungannya dengan konteks penelitian.

\section{Data dan Sumber Data}

Data dalam penelitian ini adalah data tertulis berupa teks cerita yang mengandung nilai-nilai pendidikan karakter dalam novel Kidung dari Negeri Apung Karya Arsyad Salam.

Sumber data dalam penelitian ini adalah novel Kidung dari Negeri Apung Karya Arsyad Salam yang diterbitkan oleh Penerbit Gramedia Pustaka Utama cetakan ke-I April 2015, Tebal : 192. Halaman, berat buku 500 gr.

\section{Teknik Pengumpulan Data}

Teknik yang akan digunakan untuk mengumpulkan data dalam penelitian ini adalah baca-catat. Teknik baca adalah membaca secara berulang kali dengan menelaah novel Kidung dari Negeri Apung Karya Arsyad Salam. Teknik catat digunakan untuk mencatat kata, kalimat, paragraf yang mengandung nilai-nilai pendidikan karakter dalam novel Kidung dari Negeri Apung karya Arsyad Salam. Adapun teknik pengumpulan data dalam penelitian ini sebagai berikut :

I. Membaca komperhensif novel Kidung dari Negeri Apung Karya Arsyad Salam namun berulang-ulang untuk mengidentifikasi nilai-nilai pendidikan yang terdapat dalam novel Kidung dari Negeri Apung Karya Arsyad Salam.

2. Mencatat semua kata, kalimat, paragraf, dan dialog dalam teks yang mengandung nilai-nilai pendidikan karakter dalam novel Kidung dari Negeri Apung Karya Arsyad Salam.

3. Menandai (menggaris bawahi) bagian semua kata, kalimat, paragraf, dan dialog dalam teks yang mengandung nilai-nilai pendidikan karakter dalam novel Kidung dari Negeri Apung Karya Arsyad Salam.

\section{Teknik Analisis Data}

Data dalam penelitian ini akan dianalisis dengan menggunakan pendekatan objektif sastra yang bertujuan untuk menelaah nilai pendidikan karakter dalam novel Kidung dari Negeri Apung Karya Arsyad Salam.

Adapun langkah-langkah yang dilakukan dalam penelitian ini adalah sebagai berikut. 
a. Membaca secara keseluruhan teks novel Kidung dari Negeri Apung Karya Arsyad Salam secara berulang-ulang.

b. Mencari nilai-nilai pendidikan karakter novel Kidung dari Negeri . Karya Arsyad Salam.

c. Menganalisis nilai-nilai pendidikan karakter dalam novel Kidung dari Negeri Apung Karya Arsyad Salam.

d. Melaporkan hasil analisis dalam bentuk pemaparan dan tulisan.

\section{HASIL DAN PEMBAHASAN}

Novel Kidung dari Negeri Apung karya Arsyad Salam merupakan sebuah novel yang berlatar belakang budaya Bajo. Dalam novel ini terdapat nilai pendidikan karakter yang diantaranya dapat di aplikasikan dalam pembelajaran di sekolah. Adapun nilai pendidikan karakter yang terdapat dalam novel Kidung dari Negeri Apung karya Arsyad Salam dikutip seperti berikut:

\section{Kerja Keras}

Perjuangan seorang wanita yang bernama Liana yang berjuang keras untuk menyadarkan warga akan pentingnya sebuah pendidikan di Kampung Mekar. Perjuangan Liana yang dikisahkan oleh pengarang mengalami kesulitan, dikarenakan masyarakat Kampung Mekar lebih memilih anak mereka membantu mencari ikan dan melaut daripada mengenyam pendidikan di bangku sekolah dasar. Hal tersebut didukung dengan kutipan di bawah ini.

\section{Peduli Sosial}

Melihat realita sosial yang terjadi di kampungnya tentang tidak peduli nya orang tua terhadap pendidikan anaknya, membuat Liana resah. Rasa kepeduliannya terhadap hak-hak anak untuk bersekolah membuatnya melakukan segala cara agar anak-anak tersebut dapat bersekolah. Usaha terakhir Liana yang mendatangi rumah warga untuk mendaftarkan anak mereka sekolah membuat warga merasa tak senang akan sikap Liana. Hal ini yang memicu sekitar tiga puluh orang tua murid mendatangi sekolah untuk mendemo Liana.

\section{Peduli Lingkungan}

Ketika Jayadi menyambangi rumah Sandro Dama. Terkait kutipan di atas, teradapat nilai pendidikan, yakni "peduli lingkungan". Di rumahnya, Sandro Dama memberikan nasihat-nasihat dan falsafah hidup, khususnya falsafah hidup sebagai seorang nelayan. Nasihat-nasihat inilah yang membuat Jayadi sering mengunjungi rumah Sandro Dama untuk sekedar meminta masukan atau nasihat dalam menyelesaikan segala permasalahan hidupnya. Seperti yang dikutip di bawah ini:

\section{Rasa Ingin Tahu}

Anak-anak SMP Kendari yang mengikuti tamasya terumbu karang yang dicanangkan oleh Liana. Di atas perahu mereka menanyakan segala apapun yang mereka lihat dari dasar laut tersebut. Segala macam biota laut dari ikan, 
rumput laut hingga terumbu karang yang mereka lihat, mereka tanyakan pada Awing selaku pemandu program tersebut. Awing pun dengan sabar berusaha menjawab semua pertanyaan mereka dan menuntaskan rasa ingin tahu mereka.

\section{Tanggung Jawab}

Percakapan antara Awing dan Liana. Liana memiliki cita-cita untuk menjadi seorang guru. Ia pun ingin memajukan pendidikan warga kampung nelayan.

Tanggung jawab Liana untuk memajukan Kampung Mekar, khususnya di dunia pendidikan. mengalami beberapa rintangan dan juga pertentangan dari masyarakat Kampung Mekar sendiri. Puncaknya adalah ketika para orang tua murid berbondong-bondong mendatangi Liana, dan meminta Kepala Sekolah untuk memecat Liana. Hal ini dipicu lantaran orang tua murid SD tidak suka jika anak mereka sudah tidak membantu mencari ikan dan melaut, melainkan lebih memilih belajar di sekolah.

\section{Cinta Tanah Air}

Liana yang berjuang keras untuk menyadarkan warga Kampung Nelayan terkait pentingnya sebuah pendidikan bagi anak-anak. Ia berusaha keras dan tak putus asa meski telah didemo warga atas sikapnya tersebut. Jika melihat keadaan dalam cerita, sejatinya bisa saja ia mencari sekolahan di daerah lain dan lebih layak untuknya bekerja disana.

\section{Cinta Damai}

Sikap cinta damai yang ditunjukkan dalam novel adalah ketika Pak Nurdin menghalau massa yang dating ke sekolah untuk mendemo Liana. Selaku Kepala Sekolah yang mengerti dengan niat baik Liana, Pak Nurdin membela Liana. ia menasehati warga yang datang ke sekolah.

\section{Komunikatif}

Novel ini mengandung nilai pendidikan yang dimaksud, yakni komunikatif. Hal ini ditunjukkan dengan beberapa tokoh, khususnya tokoh utama. Tokoh utama yang memiliki keinginan untuk memajukan taraf pendidikan di Kampung Nelayan, membuatnya harus berhubungan dengan beberapa individu, di antaranya dengan warga ketika mendatangi rumah warga untuk mendaftarkan anak mereka bersekolah, dengan Pak Camat ketika sedang mengurus surat izin mengadakan tamasya terumbu karang bagi anakanak SMP, dan dengan Pak Nurdin ketika mengusulkan untuk memperpanjang masa penerimaan murid baru.

\section{Kreatif}

Kejadian tersebut terjadi saat Liana mempresensi kelas. Ia resah, ia masih memikirkan mengapa warga kampung nelayan khususnya Kampung Mekar tidak memikirkan pendidikan anak-anak mereka. Liana berpikir keras dan mencari cara bagaimana membangkitkan kesadaran masyarakat akan pentingnya sebuah pendidikan. Ia teringat ketika ia pertama kali bertugas 
sebagai guru bantu di sekolah tersebut. Ketika itu bertepatan dengan penerimaan murid baru. Setelah tiga hari pembukaan penerimaan murid baru, Liana tidak melihat antusias warga, dan bahkan tidak ada satu pun murid yang mendaftar.

\section{Mandiri}

Awing memiliki karakter mandiri yang selalu berpegang teguh pada adat istiadat kampung nelayan dan memiliki watak yang tegar dalam menghadapi segala cobaan. Diceritakan karakter mandiri dan kuat yang dialami oleh tokoh ini ketika peristiwa naas menimpa ayahnya, Puto Mastahang. Dalam cerita digambarkan bahwa Awing merasakan beban psikologis yang berat. Di depan mayat ayahnya yang tewas karena ledakan bom Molotov yang akan digunakan ayah Awing untuk mendapatkan ikan di laut, ia hanya bisa terdiam di depan mayat ayahnya. Tidak menangis ataupun sedih. Sesuai dengan adat yang berlaku maka Awing pun berusaha tetap tegar menghadapi kenyataan tersebut.

\section{Kesimpulan}

Berdasarkan hasil penelitian dan pembahasan dapat disimpulkan bahwa terdapat nilai-nilai pendidikan karakter dalam novel Kidung dari Negeri Apung karya Arsyad Salam diantaranya kerja keras, peduli sosial, peduli lingkungan, rasa ingin tahu, tanggung jawab, cinta tanah air, cinta damai, komunikatif, kreatif, dan mandiri. Nilai pendidikan karakter tersebut memberikan efek positif bagi pembaca novel Kidung dari Negeri Apung karya Arsyad Salam khususnya guru dan siswa di SMA Negeri 2 Raha.

\section{Daftar Pustaka}

Depdiknas. 2008. Panduan Pengembangan Bahan Ajar. Dirjen MPDM Direktorat Pembinaan SMA.

Depdiknas. 2006. Pedoman Memilih dan Menyusun Bahan Ajar. Dirjen MPDM Direktorat SMP.

Hulukati, Wenni. 2016. Panduan Pendidikan Karakter Bagi Siswa SMA. Gorontalo: UNG Press.

Kemendikbud. 2017. Konsep dan Pedoman: Penguatan Pendidikan Karakter. Pusat Analisis dan Kebijakan Sekjen Kemendikbud.

Kemendiknas. 2oro. Panduan Pendidikan Karakter di SMP. Dirjen MPDM Direktorat SMP.

Kemendiknas. 20ı. Bahan Pelatihan: Pengembangan Pendidikan Budaya dan Karakter Bangsa. Badan Penelitian dan Pengambangan Pusat Kurikulum.

Kokasih, E. 2008. Apresiasi Sastra Indonesia. Jakarta: Nobel Edumedia.

Musthafa, Bachrudin. 2008. Teori dan Praktik Sastra dalam Penelitian dan Pengajaran. Bandung: Pascasarjana UPI.

Nugraha, Firman. 2008. Ihwal Pengajaran Sastra. Bandung: Titik Kulminasi. 
Nurgiyantoro, Burhan. 2002. Teori Pengkajian Fiksi. Yogyakarta: Gajah Mada University Press.

Nurgiyantoro, Burhan. 1995. Penilaian dalam Pengajaran Bahasa dan Sastra. Yogyakarta: BPFE.

Salam, Arsyad. 2015. Kidung dari Negeri Apung. Jakarta: Gramedia Pustaka Utama.

Sarbaini (ed). 2016. Membangun Karakter Kemanusiaan, Membentuk Kepribadian Bangsa melalui Pendidikan. Banjarmasin: Aswaja Presindo.

Sarbaini. 2014. Good Practices: Pendidikan Nilai, Moral dan Karakter Kepatuhan di Sekolah. Yogyakarta: Aswaja Presindo.

Suwondo, Tirto. 2orr. Studi Sastra: Konsep Dasar Teori dan Penerapannya pada Karya Sastra. Yogyakarta: Gama Media.

Taum, Yoseph Yapi. 1997. Pengantar Teori Sastra. Ende: Nusa Indah.

Wibowo, Agus. 2013. Pendidikan Karakter Berbasis Sastra. Yogyakarta: Pustaka Pelajar.

Widodo, C. dan Jasmadi. (2008). Buku Panduan Menyusun Bahan Ajar. Jakarta: PT Elex Media Komputindo. 